\title{
Determination of Hematological Effects of Methanolic Leaf Extract of S. incanum in Normal Mice
}

Njagi J Muriithi*, Gitahi S Maina, Njagi M Mugendi, Mwangi B Maina, Mworia J Kiambi, Juma K Kelvin, Aliyu Umar, Mwonjoria K John, Njoroge W Ann, Abdirahman YA, Ngugi M Piero and Njagi NM Eliud

Department of Biochemistry and Biotechnology, Kenyatta University, P.O Box 43844-00100, Nairobi, Kenya

\begin{abstract}
Medicinal plants and herbs have been used for ages for the purposes of enhancing and maintaining health and organic resistance against body infection. This is due to their ready availability and arguably efficacious state, therefore offering an alternative remedy in enhancing hematological parameters. Various chemical constituents of Solanum incanum (Linn) are believed to possess therapeutic effects on hematological parameters, but these effects have not been subjected to systematic scientific studies to substantiate and ascertain the therapeutic claims made regarding their clinical utility. This study investigates the hematological effects of $S$. incanum (Linn) in normal mice. The experimental mice groups were treated with methanolic seed extracts of $S$. incanum (Linn) at concentrations of $50 \mathrm{mg} / \mathrm{kg}$ and $100 \mathrm{mg} / \mathrm{kg}$ orally once per two days for a period of fourteen days. Hematological parameters and indices of unclotted blood were determined using standard protocols. Phytochemicals were determined using standard protocols. Seven and fourteen days after administration of methanolic seed extracts of $S$. incanum at the dose level of $50 \mathrm{mg} / \mathrm{kgbw}$, there was significant increase in erythrocytes, hemoglobin and hematocrit counts while the dose level of $100 \mathrm{mg} / \mathrm{kgbw}$ caused significant increase in hematocrit count fourteen days after administration of the extract. There was a significant increase in levels of total white blood cells, neutrophils and basophil counts seven and fourteen days after administration of the methanolic seed extract of $S$. incanum at the dose level of 50 $\mathrm{mg} / \mathrm{kgbw}$. The dose level of $50 \mathrm{mg} / \mathrm{kgbw}$ of methanolic seed extract of $\mathrm{S}$. incanum caused a significant increase in platelet, plateletcrit, MPV, and PDW profiles after seven days. In addition phytochemical screening results showed that the seed extract of $S$. incanum (Linn) had phytochemicals associated with erythropoietin promoting activity, immunostimulatory activities and thrombopoietin stimulation.
\end{abstract}

Keywords: Hematological disorders; Solanum incanum; Seed extract; Erythropoietin promoting activity; Immunostimulatory activities; Thrombopoietin stimulation

\section{Introduction}

Blood transports nutrients and oxygen to body cells and removes waste products away from the cells [1]. It is a composite of erythrocytes, leucocytes, thrombocytes, plasma and accounts for $7 \%$ of human body weight [2].

Oxygen distribution to the periphery from the lungs through the pulmonary capillaries, removal of carbon dioxide from the tissues back to the lungs through the systemic capillaries and maintenance of acidic and basic values of the body are the three main functions of erythrocytes [3]. Leucocytes are the main cells of the immune system that provide innate and specific adaptive immunity. They are further divided into five different classes which include; basophils, neutrophils, eosinophils, lymphocytes and monocytes [4]. Platelets play a major role in hemostasis, thrombosis, clot retraction, vessel constriction and repair, inflammation including promotion of atherosclerosis, host defense and even tumor growth/metastasis [5].

Testing of hematological indices can be used to determine the extent of deleterious effect of foreign compounds including plant extracts on the blood composition of animals [6].

WHO defines anemia as hemoglobin level of $13 \mathrm{~g} / \mathrm{dl}$ or lower for men and $12 \mathrm{~g} / \mathrm{dl}$ or lower for women [7]. Acquired anemia associated with hematopoietic abnormalities or inherited anemia may cause symptoms arising due to decreased oxygen delivery to tissue, thereby warranting blood transfusion [8]. Patients with anemia due to chronic kidney disease require administration of erythropoiesis-stimulating agents (ESA) which effectively corrects the condition. Erythropoietin is administered to improve hemoglobin in solid organ recipient patients to improve hemoglobin levels [9]. Certain drugs such as methyldopa, some anti-biotics and hydrochlorothiazide that cause drug related anemia should be substituted or discontinued to correct the drug related anemia condition [10]. Use of anti-thymocyte globulin or allogenic bone marrow transplantation and hemopoietic growth factors such as granulocyte colony stimulating factor is advised in patients with aplastic anemia [11].

A reduction in the production of white blood cells or increased utilization and destruction, or both results to neutropenia. Under conditions where the etiological factor is identifiable like the case of drugs, folic acid deficiency, treatment should be instituted without delay [12]. Hematopoietic stem cell transplantation can successfully be used in treatment of severe congenital neutropenia in cases were patient fails is to respond to granulocyte colony-stimulating factor treatment [13].

Thrombocytopenia occurs when the platelet count falls below 150 $\mathrm{x} 10^{9} / \mathrm{L}[14]$. A reduction in platelet production, platelet survival, and

*Corresponding author: Njagi J Muriithi, Department of Biochemistry and Biotechnology, Kenyatta University, P.O Box 43844-00100, Nairobi, Kenya, Tel. +254 726375 834; E-mail: jimnjagi2014@gmail.com

Received September 22, 2015; Accepted October 13, 2015; Published October 16,2015

Citation: Muriithi NJ, Maina GS, Mugendi NM, Maina MB, Kiambi MJ, et al.(2015) Determination of Hematological Effects of Methanolic Leaf Extract of $S$. incanum in Normal Mice. Pharm Anal Acta 6: 429. doi:10.4172/21532435.1000429

Copyright: ( 2015 Muriithi NJ, et al. This is an open-access article distributed under the terms of the Creative Commons Attribution License, which permits unrestricted use, distribution, and reproduction in any medium, provided the original author and source are credited. 
dilution of platelet numbers resulting from transfusion of platelet-poor blood can cause this condition [15]. Disorders of platelet adhesion, idiopathic alpha, disorders of platelet granules [16] or acquired platelet function disorders including medication and chemicals, chronic kidney disease and myeloproliferative disorders cause platelet function disorders that may be inherited [17]. Emergent plasma exchange is the cornerstone of TTP treatment [18], while short "pulses" of dexamethasone have been found to be very effective in initial management of immune thrombocytopenia [19].

Most conventional ways of managing anemia, neutropenia and thrombocytopenia are costly, have arguably many undesired side effects, less effective and painful to the patients or are not easily accessible.

All these shortcomings that arise in the use of conventional methods to manage hematological disorders require the need to look for alternative safer and effective remedies to contain and manage these hematological disorders.

Certain medicinal plants and herbs are believed to enhance health and improve resistance against infection through conditioning the body tissues and re-establishing body equilibrium [20].

S. incanum (Linn) is used by several East African communities as a remedy for tooth-ache, stomach-ache, fever, and chest pains, snake bite and ear ache [21]. Leaf, root and fruit decoctions are drank, roots are chewed and sap swallowed, leaf sap is used for washing painful areas and ash of burnt plant is mixed with fat and applied externally [22].

The plant is employed in East and Southern Africa for the treatment of skin diseases, general infections, abdominal pains, fever, stomachache and indigestion. In addition the fruit is used for the treatment of dandruff, skin diseases, sores and wounds in Tanzania [23].

In Niger, Sudan, Rwanda and Namibia the fruits are used as an ingredient of arrow poison and in Mozambique of fish poison [24]. In southern part of Ethiopia, haddiya people use the root of the plant to get relief from stomach problem, the root is chewed and sap swallowed. Fruit sap is mixed with butter and applied to cattle to control ticks [25]

Therefore, this study was aimed at evaluating the hematological effects of methanolic seed extract of Solanum incanum (Linn) on normal mice as a preliminary step towards development of a more efficacious plant-derived agent to manage hematological disorders and boost health.

\section{Collection and preparation of sample materials}

Ripe fruits of S. incanum (Linn) were collected from Siakago division, Mbeere North sub-county, Embu County, Kenya. Ripe fruits were identified with the help of local herbalists. The information gathered included vernacular names, plant parts used and the ailment treated. The samples were properly sorted out and transported in polythene bags to Kenyatta University, Biochemistry and Biotechnology laboratories for drying and crushing. The identity of the plant was authenticated by a taxonomist in the Department of Plant and Microbial Sciences, Kenyatta University. A voucher specimen of the plant was deposited at the University's Herbarium for future reference. Ripe fruits of S. incanum (Linn) were cleaned with tap water to remove dirt and debris on the surface then cut to separate the pericarp and the seeds. The seeds were then dried under a shade and ground into powder using an electrical blender.

\section{Extraction}

Five hundred milligrams of the seed powder was weighed and soaked in $1 \mathrm{~L}$ of methanol in a conical flask. The flask was shaken, corked and left to stand for $48 \mathrm{hrs}$ at room temperature. The mixture was then filtered using Whatman No. 1 filter paper and the filtrate Rota- evaporated to dryness at $65^{\circ} \mathrm{C}$ to recover the extract. The concentrate was put in an air tight container and stored at $4^{\circ} \mathrm{C}$ before use in bioassay studies.

\section{Experimental animals and design}

Three to four week old healthy male Swiss albino mice weighing an average of $20 \mathrm{~g}$ were used in this study. They were bred in the animal house of the Department of Biochemistry and Biotechnology, Kenyatta University. The mice were housed in polypropylene cages, maintained under standard laboratory conditions of 12 hour light and dark sequence, at ambient temperature of $25 \pm 2^{\circ} \mathrm{C}$ and $35-60 \%$ humidity. The animals were fed with standard mice pellets obtained from Unga Feeds Limited, Kenya, and water ad libitum. Ethical guidelines and procedures for handling experimental animals were followed.

The animals were randomly divided into 2 groups (Group A and B) of 5 mice each. Animals in Group A and B were orally administered with $50 \mathrm{mg} / \mathrm{kgbw}$ and $100 \mathrm{mg} / \mathrm{kgbw}$ of methanolic extract respectively at intervals of two days for 14 days. The extract was administered using intragastric gavage technique. Blood from both groups of mice was taken before the commencement of the first oral administration, then repeated on the seventh day and at the end of the experimental period. During this period, mice were allowed free access to mice pellet and water and observed for any signs of general illness, change in behavior and/or mortality.

\section{Preparation of extracts doses for administration}

The dose level of $50 \mathrm{mg} / \mathrm{kgbw}$ was prepared by dissolving $0.042 \mathrm{~g}$ of the extract in $4.2 \mathrm{ml}$ of $3 \%$ dimethylsulfoxide and topping up to $10 \mathrm{ml}$ with distilled water, while the dose level of $100 \mathrm{mg} / \mathrm{kgb}$ was prepared by dissolving $0.084 \mathrm{~g}$ in $4.2 \mathrm{ml}$ of $3 \%$ dimethylsulfoxide and topping up to $10 \mathrm{ml}$ with distilled water.

\section{Collection of blood samples}

Blood samples were collected at the start of the experiment, then on the $7^{\text {th }}$ day and finally on the $14^{\text {th }}$ day from the tails of mice for the determination of hematological parameters. The tails were first sterilized by swabbing with $70 \%$ ethanol and then the tip of the tails snipped with sterile scissors. Bleeding was enhanced by gently milking the tail from the body towards the tip. Blood of approximately $0.2 \mathrm{ml}$ was drawn into bottles containing anticoagulant (EDTA) shaken and taken for hematological parameter assessment. On the $14^{\text {th }}$ daythe animals were euthanized by use of chloroform.

\section{Determination of hematological parameters}

Hematological parameters and indices were determined from unclotted blood samples using standard protocols [26]. Erythrocytes, hemoglobin concentration, hematocrit, mean corpuscular volume, mean corpuscular hemoglobin, mean corpuscular hemoglobin concentration, red cell distribution width and platelets, plateletcrit, mean platelet volume and platelet distribution width, were determined using the Coulter Counter System (Beckman Coulter ${ }^{\oplus}$, ThermoFisher, UK). Air-dried thin blood films stained with Giemsa stain were examined microscopically by magnification X100 using immersion oil for differential white blood cell counts. 


\section{Qualitative phytochemical screening}

The crude extract obtained was subjected to qualitative phytochemical screening to identify presence or absence of selected chemical constituents using methods of analysis as described by $[27,28]$.Standard screening tests for detecting the presence of different chemical constituents were employed. Secondary metabolites tested included alkaloids, flavonoids, phenolics, saponins, terpenoids, cardiac glycosides, steroids and tannins.

\section{Data management and analysis}

Experimental data on different hematological parameters was obtained from all the animals on day zero and compared with the $7^{\text {th }}$ and $14^{\text {th }}$ day for the two dose levels. It was recorded and tabulated on a broad sheet using Ms Excel program. The results were expressed as mean \pm standard error of mean (SEM) for analysis. Statistical significance of difference among the two groups were analyzed using one-way analysis of variance (ANOVA) followed by Tukey's tests to separate the means and obtain the specific significant differences among the different groups. The values of $\mathrm{P} \leq 0.01$ were considered to be significant. Analysis of the data was done using Minitab statistical software.

\section{Results}

\section{Effects of methanolic extract of $S$. incanum (Linn) on eryth-} rocytic parameter profiles in normal mice

The methanolic seed extract of S. incanum (Linn) induced changes in erythrocytes and related parameter profiles in normal mice (Table 1). Seven and fourteen days after administration of the extracts at the dose levels of $50 \mathrm{mg} / \mathrm{kgbw}$, there was significant increase in erythrocytes, $\mathrm{Hb}$ and hematocrit counts $(\mathrm{p}<0.01$; Table 1$)$. The dose level of 100 $\mathrm{mg} / \mathrm{kgbw}$ had no significant effect on erythrocyte counts. However, it caused significant increase in $\mathrm{Hb}$ concentration seven and fourteen days after administration of the extracts $(\mathrm{P}<0.01$; Table 1$)$. Besides, as Table 1 shows, the dose level of $100 \mathrm{mg} / \mathrm{kgbw}$ caused significant increase in hematocrit count fourteen days after administration of the extracts. The two dose levels had no significant effects on MCV, MCH, MCHC and RDW profiles in normal mice ( $\mathrm{p}>0.01$; Table 1$)$.

\section{Effects of methanolic extract of S. incanum (Linn) in total WBC and differential WBC counts in normal mice}

The methanolic seed extract of S. incanum (Linn) induced changes in total and differential WBC counts in normal mice (Table 2). Seven and fourteen days after administration of the extracts at the dose levels of $50 \mathrm{mg} / \mathrm{kgbw}$, there was a significant increase in levels of total WBC, neutrophils and basophil counts $(\mathrm{p}<0.01$; Table 2$)$. There was also a significant increase in levels of WBC counts at the dose level of 100 $\mathrm{mg} / \mathrm{kgbw}$ after fourteen days and on basophil counts after seven days of administration of the extract ( $<<0.01$; Table 2$)$. The dose level of 50 $\mathrm{mg} / \mathrm{kgbw}$ caused a significant increase in basophil counts after fourteen days compared to seven days after administration ( $<<0.01$; Table 2). The two dose levels had no significant effects on lymphocyte, monocyte and eosinophil profiles in normal mice ( $\mathrm{p}>0.01$; Table2).

\section{Effects of methanolic extract of S. incanum (Linn) in Platelets} and their related parameter profiles in normal mice

The methanolic seed extract of S. incanum (Linn) caused changes in platelets and their related parameters in normal profiles (Table 3 ). The dose level of $50 \mathrm{mg} / \mathrm{kgbw}$ caused a significant increase in platelet, plateletcrit, MPV, and PDW profiles after seven days of oral administration ( $\mathrm{p}<0.01$; Table 3 ). The dose level of $100 \mathrm{mg} / \mathrm{kgbw}$ caused a significant increase in platelet and MPV profiles seven days after oral administration $(\mathrm{p}<0.01$; Table 3$)$. It also caused a significant increase in pleteletcrit after seven and fourteen days of oral administration $(\mathrm{p}<0.01$; Table 3$)$ but did not have any significant effect on PDW ( $>0.01$; Table 3$)$.

\section{Phytochemical screening}

Qualitative phytochemical screening of the methanolic crude seed extract of $S$. incanum (Linn) revealed presence of alkaloids, phenolics, terpenoids, saponins and tannins (Table 4).

\section{Discussion}

The actual physiological status of organisms can be diagnosed through use of blood parameters. For normal functioning of the body of an organism, it must keep its blood composition and constituent under natural conditions [29]

The present study showed that methanolic seed extract of $S$. incanum (Linn) demonstrated varying degrees of hematological changes at the dose levels of $50 \mathrm{mg} / \mathrm{kgbw}$ and $100 \mathrm{mg} / \mathrm{kgbw}$.

The significant increase in erythrocytes and hematocrit counts after oral administration of methanolic extract of S. incanum (Linn) suggests that the extract may contain phytochemicals and compounds that stimulate the secretion or formation of erythropoietin in the stem cells of normal mice. Stimulation of stem cells in the bone marrow to produce red blood cells occurs due to the action of erythropoietin which is a glycoprotein hormone [30]. It affects the oxygen-carrying capacity of the blood and the amount of oxygen delivered to the tissues since red blood cells and hemoglobin are very important in transferring respiratory gases $[31,32]$.

It may also suggest that the extract can cause polychethermia which is in agreement with previous studies that indicated that an increase in the count of erythrocytes and PCV is suggestive of polycythermia and positive erythropoiesis [33-36]. In addition previous studies by [37] showed that the leaves of Peristrophe bicalculata (Retz) are capable of improving erythrocyte counts in experimental animals. They confirmed the use of Peristrophe bicalculata (Retz) leaves in restoring lost blood during excessive bleeding. In his studies [38] worked on Baphia nitida (Lodd) also reported similar results. Therefore, the methanolic extracts of S. incanum (Linn) can be used to restore lost blood during excessive bleeding.

Research by [39] suggested that the mechanism leading to the increase in erythrocyte count is probably mediated by the antioxidant property of extracts. Presence of antioxidant phytochemicals like terpenoids and tannins in the methanolic extract of S. incanum (Linn) may be responsible for the haemopoietic stimulating effects. This agrees with previous research that showed that prophylactic and therapeutic oral administration of anti-oxidant supplements in plant extracts significantly increased cells of hemopoietic origin in animals exposed to potentially lethal dose of radiation [39]. Erythrocytes have found to be protected from oxidative damage by flavonoids, tannins and terpenes [40].

Though the extract stimulated the production of red blood cells and hemoglobin, it could have had an inhibitory effect on hemoglobin incorporation into red blood cells and a consequent reduction in oxygen exchange. This is in line with [41] findings, that $\mathrm{MCHC}, \mathrm{MCH}$ and MCV profiles relate to individual red blood cells while hemoglobin 
Citation: Muriithi NJ, Maina GS, Mugendi NM, Maina MB, Kiambi MJ, et al.(2015) Determination of Hematological Effects of Methanolic Leaf Extract of S. incanum in Normal Mice. Pharm Anal Acta 6: 429. doi:10.4172/21532435.1000429

Page 4 of 6

\begin{tabular}{|c|c|c|c|c|c|c|}
\hline \multirow[t]{2}{*}{ Parameters } & \multicolumn{3}{|c|}{$50 \mathrm{mg} / \mathrm{kgbw}$} & \multicolumn{3}{|c|}{$100 \mathrm{mg} / \mathrm{kgbw}$} \\
\hline & Day 0 & Day 7 & Day 14 & Day 0 & Day 7 & Day 14 \\
\hline Erythrocytes $\left(\mathrm{X} 10^{6} \mu \mathrm{L}\right)$ & $6.12 \pm 0.19^{a}$ & $7.41 \pm 0.06^{b}$ & $8.16 \pm 0.44^{b}$ & $5.56 \pm 0.18^{a}$ & $7.12 \pm 0.38^{a}$ & $7.12 \pm 0.38^{a}$ \\
\hline $\mathrm{Hb}(\mathrm{g} / \mathrm{dl})$ & $9.36 \pm 0.32^{\mathrm{a}}$ & $11.52 \pm 0.41^{\mathrm{ab}}$ & $13.74 \pm 0.69^{b}$ & $7.30 \pm 0.61^{\mathrm{a}}$ & $11.42 \pm 0.38^{b}$ & $15.08 \pm 0.48^{c}$ \\
\hline Hematocrit (\%) & $33.79 \pm 2.17^{a}$ & $36.77 \pm 4.17^{\mathrm{ab}}$ & $56.44 \pm 4.03^{b}$ & $29.64 \pm 1.42^{a}$ & $43.02 \pm 2.47^{a}$ & $61.46 \pm 2.79^{b}$ \\
\hline $\mathrm{MCV}(\mathrm{fL})$ & $59.62 \pm 2.07^{a}$ & $60.52 \pm 1.86^{a}$ & $70.30 \pm 3.82^{a}$ & $61.98 \pm 0.98^{a}$ & $60.76 \pm 3.61^{a}$ & $65.32 \pm 3.89^{a}$ \\
\hline MCH (Pg) & $15.58 \pm 0.11^{\mathrm{a}}$ & $17.10 \pm 0.54^{a}$ & $17.14 \pm 0.38^{a}$ & $15.14 \pm 0.36^{a}$ & $16.10 \pm 0.35^{a}$ & $15.98 \pm 0.45^{\mathrm{a}}$ \\
\hline MCHC (g/dl) & $25.62 \pm 0.78^{a}$ & $28.28 \pm 0.30^{a}$ & $24.54 \pm 1.04^{a}$ & $24.48 \pm 0.87^{a}$ & $26.94 \pm 1.35^{a}$ & $24.66 \pm 1.00^{a}$ \\
\hline RDW (\%) & $15.18 \pm 0.50^{\mathrm{a}}$ & $15.54 \pm 0.37^{a}$ & $16 \pm 14 \pm 0.25^{a}$ & $15.76 \pm 0.28^{a}$ & $16.42 \pm 0.75^{a}$ & $16.34 \pm 0.46^{a}$ \\
\hline
\end{tabular}

All values are expressed as mean \pm SEM for five animals per group. Values for each parameter are compared among day 0,7 and 14 for each dose by ANOVA and Tukey's post hoc test

Table 1: Effects of methanolic seed extract of S. incanum (Linn) on erythrocytic parameter profiles in normal mice.

\begin{tabular}{|c|c|c|c|c|c|c|}
\hline \multirow{2}{*}{ Parameters } & \multicolumn{3}{|c|}{$50 \mathrm{mg} / \mathrm{kgbw}$} & \multicolumn{3}{|c|}{$100 \mathrm{mg} / \mathrm{kgbw}$} \\
\hline & Day 0 & Day 7 & Day 14 & Day 0 & Day 7 & Day 14 \\
\hline 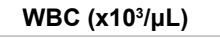 & $6.10 \pm 0.53^{a}$ & $8.28 \pm 0.89^{a b}$ & $10.78 \pm 0.35^{b}$ & $5.56 \pm 0.32^{\mathrm{a}}$ & $6.78 \pm 0.48^{a}$ & $10.70 \pm 0.51^{b}$ \\
\hline Neutrophils (\%) & $1.14 \pm 0.15^{\mathrm{a}}$ & $1.62 \pm 0.11^{\mathrm{ab}}$ & $2.24 \pm 0.22^{b}$ & $1.24 \pm 0.23^{a}$ & $1.50 \pm 0.28^{a}$ & $1.90 \pm 0.38^{a}$ \\
\hline Lymphocytes (\%) & $4.58 \pm 0.38^{a}$ & $4.28 \pm 0.28^{a}$ & $3.94 \pm 0.22^{\mathrm{a}}$ & $3.98 \pm 0.17^{\mathrm{a}}$ & $3.98 \pm 0.12^{\mathrm{a}}$ & $4.40 \pm 0.45^{\mathrm{a}}$ \\
\hline Monocytes (\%) & $0.02 \pm 0.02^{\mathrm{a}}$ & $0.26 \pm 0.06^{a}$ & $0.12 \pm 0.07^{\mathrm{a}}$ & $0.02 \pm 0.02^{\mathrm{a}}$ & $0.28 \pm 0.11^{\mathrm{a}}$ & $0.34 \pm 0.05^{\mathrm{a}}$ \\
\hline Eosinophils (\%) & $0.00 \pm 0.00^{a}$ & $0.04 \pm 0.04^{a}$ & $0.12 \pm 0.04^{a}$ & $0.06 \pm 0.04^{a}$ & $0.00 \pm 0.00^{a}$ & $0.04 \pm 0.02^{\mathrm{a}}$ \\
\hline Basophils (\%) & $0.56 \pm 0.07^{a}$ & $3.00 \pm 0.05^{\mathrm{b}}$ & $4.32 \pm 0.19^{c}$ & $0.34 \pm 0.07^{a}$ & $2.22 \pm 0.21^{b}$ & $2.90 \pm 0.37^{b}$ \\
\hline
\end{tabular}

All values are expressed as mean \pm SEM for five animals per group. Values for each parameter are compared among day 0,7 and 14 for each dose by ANOVA and Tukey's post hoc test.

Table 2: Effects of methanolic seed extract of $S$. incanum (Linn) on white blood cells and their differentials parameter profiles in normal mice.

\begin{tabular}{|c|c|c|c|c|c|c|}
\hline \multirow[t]{2}{*}{ Parameters } & \multicolumn{3}{|c|}{$50 \mathrm{mg} / \mathrm{kgbw}$} & \multicolumn{3}{|c|}{100 mg/kgbw } \\
\hline & Day 0 & Day 7 & Day 14 & Day 0 & Day 7 & Day 14 \\
\hline Platelets $\left(\times 10^{3} / \mu \mathrm{L}\right)$ & $254.40 \pm 9.49^{a}$ & $451.6 \pm 16.3^{b}$ & $475.8 \pm 30.6^{b}$ & $275.40 \pm 9.57^{a}$ & $407.60 \pm 4.41^{b}$ & $420 \pm 4.52^{b}$ \\
\hline Plateletcrit (\%) & $0.20 \pm 0.13^{a}$ & $0.82 \pm 0.04^{b}$ & $1.10 \pm 0.07^{\mathrm{b}}$ & $0.07 \pm 0.01^{a}$ & $0.92 \pm 0.07^{b}$ & $1.24 \pm 0.05^{c}$ \\
\hline MPV(fL) & $1.90 \pm 0.05^{a}$ & $4.60 \pm 0.27^{b}$ & $5.42 \pm 0.19^{b}$ & $2.22 \pm 0.13^{a}$ & $4.18 \pm 0.28^{b}$ & $4.56 \pm 0.30^{b}$ \\
\hline PDW (\%) & $14.78 \pm 0.67^{a}$ & $17.80 \pm 0.32^{b}$ & $18.40 \pm 0.31^{b}$ & $15.14 \pm 0.53^{a}$ & $16.93 \pm 0.42^{\mathrm{a}}$ & $16.78 \pm 0.48^{a}$ \\
\hline
\end{tabular}

All values are expressed as mean \pm SEM for five animals per group. Values for each parameter are compared among day 0,7 and 14 for each dose by ANOVA and Tukey's post hoc test.

Table 3: Effects of methanolic seed extract of $S$. incanum (Linn) on platelets and their related parameter profiles in normal mice.

\begin{tabular}{|c|c|}
\hline Phytochemicals & S. incanum (Linn) \\
\hline Alkaloids & + \\
\hline Flavonoids & - \\
\hline Steroids & + \\
\hline Saponins & - \\
\hline Cardiac glycosides & + \\
\hline Phenolics & + \\
\hline Terpenoids & + \\
\hline Tannins & + \\
\hline
\end{tabular}

Present phytochemicals are denoted by $(+)$ sign, absent phytochemicals are denoted by (-) sign

Table 4: Qualitative phytochemical screening of crude seed extract of $S$. incanum (Linn)

and hematocrit profiles relate to the total population of red blood cells in the blood.

Agents that activate host defense mechanisms in the presence of an impaired immune responsiveness can provide supportive therapy to conventional chemotherapy. This concurs with [42] that immunomodulation through stimulation or suppression may help in maintaining a disease free state.

The significant increase in white blood cell and the differential leukocytes counts in the test animal shows that the methanolic extracts of $S$. incanum (Linn) may have immune boosting properties similar to those reported for garlic Allum sativum (Linn) by [33] and seed extracts of Citrus paradise Macfad by [43]. It has been reported that granulocyte-macrophage colony stimulating factor, macrophage colony stimulating factor, interleukins IL-2 IL-4 and IL-5 regulate the proliferation, differentiation and maturation of committed stem cells responsible for the production of white blood cells $[44,45]$.

Since the methanolic extracts of S. incanum (Linn) caused increases in white blood cell counts, it is possible that the phytocompounds in the extract stimulated the production of these regulatory factors or increased the sensitivity of the committed stem cells, responsible for the production of white blood cells, to these factors.

\section{Conclusion}

In conclusion the present study showed that oral administration of methanolic seed extract of $S$. incanum (Linn) in normal mice resulted to a significant improvement of erythrocytic parameter profiles. This may suggest that the plant possess erythropoietin promoting activity and phytochemicals that slow down the natural process of oxidative breakdown of erythrocyte hence have a promising role in treatment and/or prevention of anemia. The significant increase in total white blood cell and differential white blood cell counts in normal mice after oral administration of the extract shows that the plants may promote and improve the immune-stimulatory activities hence can be pursued for their clinical relevance in management of immunitydependent disorders. The significant increase in platelet and their related parameters in normal mice after oral administration of the 
Citation: Muriithi NJ, Maina GS, Mugendi NM, Maina MB, Kiambi MJ, et al.(2015) Determination of Hematological Effects of Methanolic Leaf Extract of S. incanum in Normal Mice. Pharm Anal Acta 6: 429. doi:10.4172/21532435.1000429

Page 5 of 6

extract demonstrate that the extract has the potential to stimulate thrombopoietin production and can thus be used to manage hemostatic capacity of blood since platelets in blood mediate clotting mechanisms. Furthermore, S. incanum (Linn) has antioxidant activity hence can contribute significantly in reducing advancing age induced oxidative stress in elderly people. This study therefore, scientifically confirms and supports the traditional use of leaves of S. incanum (Linn) in enhancing hematological parameters and improving health.

\section{Acknowledgment}

We wish to thank Mr. James Adino and Daniel Gitonga for their technical assistance.

\section{References}

1. Cheeke PR, Shull LR (1999) Natural toxicants in feeds and poisonous plants. New York: AVI Publishing.

2. Austin CC, Perkins SL (2006) Parasites in a biodiversity hotspot: a survey of hematozoa and a molecular phylogenetic analysis of Plasmodium in New Guinea skinks. J Parasitol 92: 770-777.

3. Jagger JE, Bateman RM, Ellsworth ML, Ellis CG (2001) Role of erythrocyte in regulating local $\mathrm{O}_{2}$ delivery mediated by hemoglobin oxygenation. Am J Physio Heart Circ Physiol 280: H2833-2839.

4. Mosmann TR, Coffman RL (1989) TH1 and TH2 cells: different patterns of lymphokine secretion lead to different functional properties. Annu Rev Immunol 7: $145-173$.

5. Harrison $P$ (2005) Platelet function analysis. Blood Rev 19: 111-123.

6. Ashafa AOT, Yakubu MT, Grierson DS, Afolayan AJ (2009) Effects of aqueous leaf extract from the leaves of Chrysocoma ciliate $(\mathrm{L})$ on some biochemical parameters of Wistar rats. Africa Journal of Biotechnology 8:1425-1430.

7. Price EA, Schrier SL (2008) Anemia in the elderly: introduction. Semin Hematol 45: 207-209.

8. Spivak JL (2000) The blood in systemic disorders. Lancet 355: 1707-1712.

9. Tan-Shalaby J, Tempero M (1995) Malignancies after liver transplantation: a comparative review. Semin Liver Dis 15: 156-164.

10. Blann A (2014) Routine blood tests 4: functions and diseases of red and white blood cells. Nursing Times 110: 16-18.

11. Itterbeek P, Vandenberghe P, Nevens F, Fevery J, Aerts R, et al. (2002) Aplastic anemia after transplantation for non-A, non- $B$, non- $C$ fulminant hepatic failure: case report and review of the literature. Transpl Int 15: 117-123.

12. Bodey GP, Bolivar R, Fainstein, V (1882) Infectious complications in leukemia patients. Seminar of Hematology 19: 193-220.

13. Kawaguch K, Matsubara K, Uchida Y, Miyata K, Haseqawa D, et al. (2014) Successful treatment with allogenic hematopoietic stem cell transplantation of a severe congenital neutropenia patient harboring a novel ELANE mutation. The Japanese journal of clinical hematology 55: 2294-2299.

14. Izak M, Bussel JB (2014) Management of thrombocytopenia. F1000Prime Rep 6: 45 .

15. Bradbury C, Murray J (2013) Investigating an incidental finding of thrombocytopenia. BMJ 346: f11.

16. Bolton-Maggs PH, Chalmers EA, Collins PW, Harrison P, Kitchen S, et al. (2006) A review of inherited platelet disorders with guidelines for their management on behalf of the UKHCDO. Br J Haematol 135: 603-633.

17. Konkle BA (2011) Acquired disorders of platelet function. Hematology Am Soc Hematol Educ Program 2011: 391-396.

18. Moake JL (2002) Thrombotic microangiopathies. N Engl J Med 347: 589-600.

19. Cheng Y, Wong RS, Soo YO, Chui CH, Lau FY, et al. (2003) Initial treatment of immune thrombocytopenic purpura with high-dose dexamethasone. $\mathrm{N}$ Engl J Med 349: 831-836.

20. Sumit D, Ripunjoy B, Nishant N (2014) A review on immune modulatory effect of some traditional medicinal herbs. Journal of Pharmaceutical, Chemical and Biological Science 2: 33-42.
21. Kokwaro J (1993) Medicinal plants of East Africa (2nd Edn) East Africa Literature Bureau, Nairobi.

22. Chang YC, Chang FR, Wu YC (2000) Non-steroidal Constituents from Solanum incanum (Linn). Journal of the Chinese Chemical Society 47: 247-251.

23. Liu LF, Liang CH, Shiu LY, Lin WL, Lin CC, et al. (2004) Action of solamargine on human lung cancer cells--enhancement of the susceptibility of cancer cells to TNFs. FEBS Lett 577: 67-74.

24. Bodart P, Kabengera C, Noirfalise A, Hubert P, Angenot L (2000) Determination of alpha-solanine and alpha-chaconine in potatoes by high-performance thinlayer chromatography/densitometry. J AOAC Int 83: 1468-1473.

25. Regassa A (2000) The use of herbal preparations for tick control in western Ethiopia. J S Afr Vet Assoc 71: 240-243.

26. Jain NC (1986) Schalm's veterinary hematology (4th Edn) Lea and Febiger Philadelphia.

27. Harbone JB (1998) Phytochemical Methods: A Guide to Modern Techniques of Plant Analysis ( $3^{\text {rd }}$ edn) Chapman and Hal Publishers, London 3: 60-66.

28. Kotake CK (2000) Practical Pharmacognosy, Vallabh Prakashan, New Delhi, India 4: 107-111.

29. Rodrigues B, McNeill JH (1992) The diabetic heart: metabolic causes for the development of cardiomyopathy. Cardiovasc Res 26: 913-922.

30. Ohlsson A, Aher SM (2009) Early erythropoietin for preventing red blood cel transfusion in preterm and/or low birth weight infants. Cochrane Database Sys Rev 6: 227-251.

31. Polenakovic M, Sikole A (1996) Is erythropoietin a survival factor for red blood cells? J Am Soc Nephrol 7: 1178-1182.

32. Oyedeji KO (2013) Effect of Corchorus olitorius Extract on Haematological and Plasma Biochemical Parameters in Male Albino Rats. IOSR Journal of Dental and Medical Sciences 5: 68-71.

33. Iranloye BO (2002) Effect of chronic garlic feeding on some hematological parameters. African Journal of biomedical Research 5: 81-82.

34. Mansi K, Lahham J (2008) Effects of pride of Artemisia sieberi Besser (A herba-alba) on heart rate and some hematological values in. normal and alloxan induced diabetic rats. Journal of Basic and Appliced Sciences 4: 57-62.

35. Kuppast IJ, Vasudeva NP, Ravi MC, Biradar SS (2009) Studies on the hematological effect of the extracts of Cordia dichotoma Forst. F. Fruits. Research Journal of Agriculture Science and Forestry 1: 195-204.

36. Okpuzor J, Ogbunugafor HA, Kareem GK (2009) Hepatoprotective and hematologic effects of fractions of Globimetula braunii (Engle) in normal albino rats. EXCIL Journal 8: 182-189.

37. Esenowo GJ, Sam SM, Bala DN, Ekpo BAJ, Edung EM (2010) Phytochemica screening and the hematological effect of Peristrophe bicalyculata (RETZ) diet preparation in albino rats. World Journal of Science, Technology 2: 277-281.

38. Okon JE, Esenowo GJ, Etim GJ, Umoh NS (2013) Phytochemical Screening and Hemopoetic Study of the Ethanolic Root Extract of Baphia nitida (Lodd) on Albino Rats. International Journal of Modern Biology and Medicines 3: 60-68

39. Wambi C, Sanzari J, Wan XS, Nuth M, Davis J, et al. (2008) Dietary antioxidants protect hematopoietic cells and improve animal survival after totalbody irradiation. Radiat Res 169: 384-396.

40. Grassmann J (2005) Terpenoids as plant antioxidants. Vitam Horm 72: 505 535 .

41. Adebayo JO, Adesokan AA, Olatunji LA, Burro DO, Soladoye AO (2005) Effect of Ethanolic extract of Bougainvillea spectabilis leaves on haematological and serum lipid variables in rats. Biochemistry 17: 45-50.

42. Dahanukar SA, Kulkarni RA, Rege NN (2000) Pharmacology of medicinal plants and natural products. Indian Journal of Pharmacology 32: 81-118.

43. Adeneye AA (2008) Hematopoietic effect of methanol seed extract of Citrus paradise Mac fad (grape fruit) in Westar rats. Biomedical Research 19: 23-26.

44. Guyton AC, Hall JE (2000) A Textbook of Medical Physiology (10th Edn) WB Saunders Co., Philadelphia.

45. Ganong WF (2001) Review of Medical Physiology (20th Edn) Lange Medical 
Citation: Muriithi NJ, Maina GS, Mugendi NM, Maina MB, Kiambi MJ, et al.(2015) Determination of Hematological Effects of Methanolic Leaf Extract of S. incanum in Normal Mice. Pharm Anal Acta 6: 429. doi:10.4172/21532435.1000429

Books, McGraw Hill Companies Inc, New York. 